\title{
HUBUNGAN MANAJEMEN KELAS DENGAN MOTIVASI BELAJAR ANAK KELOMPOK B TK BINA ANAPRASA NURIS JEMBER
}

\author{
(The Relationship Class Management with Learning Motivation of Children \\ Group B Kindergarten Bina Anaprasa Nuris Jember)
}

Nurul Litasari. Misno A. Latief*,, Syarifuddin.

PGPAUD FKIP Universitas Jember, Jl. Kalimantan 37, Jember 68121

E-mail: misno.alathif@yahoo.com

\begin{abstract}
Abstrak
Penelitian ini dilatarbelakangi oleh kurangnya motivasi belajar anak yang dapat menghambat proses mencapai tujuan belajar. Motivasi belajar dapat meningkat didukung dengan suasana kelas yang nyaman dan kondusif, sehingga guru perlu mengoptimalkan pengelolaan kelas (manajemen kelas) dengan baik. Tujuan penelitian ini untuk mengetahui hubungan manajemen kelas dengan motivasi belajar anak kelompok B. Responden penelitian adalah anak kelompok B dengan jumlah responden sebanyak 14 anak. Metode pengumpulan data menggunakan angket, metode observasi dan dokumentasi. Hasil penelitian yang diperoleh menggunakan rumus korelasi tata jenjang Rank Spearman (Spearman's Rho) dengan perhitungan manual yakni nilai $r_{\text {hitung }}$ sebesar 0,808 sedangkan $r_{\text {tabel }}$ sebesar 0,544 dengan taraf signifikan 5\% maka $r_{\text {hitung }}$ lebih besar dari $r_{\text {tabel }}$ sehingga $\mathrm{H}_{\mathrm{a}}$ diterima dan $\mathrm{H}_{0}$ ditolak. Apabila dikonsultasikan pada tabel pedoman interpretasi koefesien korelasi $r_{\text {hitung }}$ yang berada pada rentang 0,800 sampai 1,000 maka hubungan yang terjadi termasuk ke dalam kriteria hubungan yang kuat.
\end{abstract}

Kata Kunci: Manajemen Kelas, Motivasi Belajar

\begin{abstract}
This research is motivated by the lack of motivation to learn children which can hinder the process of achieving learning goals. Motivation to learn can be increased supported by a comfortable and conducive classroom atmosphere, so that teachers need to optimize classroom management (class management) properly. The purpose of this study was to determine the relationship between classroom management and learning motivation of children in group $B$. The research respondents were children in group B with 14 children as respondents. Methods of data collection using a questionnaire, observation and documentation methods. The results obtained using the Spearman Rank level correlation formula (Spearman's Rho) with manual calculations, namely the rcount value of 0.808 while the rtable is 0.544 with a significant level of $5 \%$, so the rcount is greater than the r table so that Ha is accepted and $\mathrm{HO}$ is rejected. When consulted on the guideline table for the interpretation of the correlation coefficient rcount which is in the range of 0.800 to 1,000, the relationship that occurs is included in the criteria for a strong relationship.
\end{abstract}

Keyword: Class Management, Learning Motivation 


\section{PENDAHULUAN}

Pendidikan merupakan usaha manusia dengan tujuan meningkatkan kualitas hidup dan kehidupan secara individu, kelompok maupun sebagai anggota dari suatu bangsa. Pendidikan dilakukan secara sadar dan terencana dalam pembelajaran yang aktif untuk mengembangkan kemampuan dan potensi yang ada dalam diri individu. Sutarman (2016) menjelaskan bahwa pendidikan dilaksanakann secara berkelanjutan dari dasar, menengah dan tinggi. Pendidikan dasar dimulai sejak usia dini. Menurut Amilda (2017) anak usia dini adalah anak yang sedang dalam proses pertumbuhan dan perkembangan yang bersifat khas. Penyampaian keinginan anak terkadang ditunjukkan dengan perilaku yang kurang diterima oleh lingkungan. Anak masih belajar mencoba dan mengulang perilaku yang dapat diterima oleh lingkungannya (Montolalu, 2009). Proses belajar anak memerlukan motivasi yang tinggi dari dalam diri, supaya hasil belajar atau tujuan dalam mencapai keinginan berjalan maksimal.

Motivasi belajar menurut Badaruddin (2015) merupakan dorongan psikologis individu untuk menjalankan suatu tindakan dalam mencapai suatu tujuan belajar. Motivasi adalah hal yang harus dipunyai anak, saat anak mempunyai motivasi belajar yang tinggi maka anak lebih bersemangat dalam menjalankan setiap proses kegiatan belajar. Menurut Clayton Alderfer (dalam Nashar, 2004:42) Motivasi belajar adalah kecenderungan seorang anak didik dalam melakukan kegiatan belajar untuk mencapai hasil belajar yang terbaik. Dorongan yang tinggi dalam belajar membantu dalam proses penyerapan informasi dan penguasaan materi pada setiap kegiatan pembelajaran anak. Berdasarkan dari pendapat hali di atas maka dapat disimpulkan motivasi belajar merupakan kecenderungan psikologis anak didik disertai dengan suatu kegiatan belajar untuk mencapai tujuan pembelajaran atau prestasi belajar.

Motivasi belajar anak bisa dipengaruhi oleh banyak hal, salah satu yang utama adalah adanya suasana kelas yang nyaman terkait dengan manajemen kelas. Hal itu sesuai dengan yang disampaikan Zulqadry (2015) yang menyatakan bahwa bahwa motivasi anak selama proses pembelajaran akan meningkat jika didukung dengan suasana kelas yang nyaman dan kondusif. Oleh karena itu, dengan manajemen kelas yang baik didukung nyamannya suasana di kelas akan lebih merangsang rasa antusias anak dalam kegiatan pembelajaran sehingga anak lebih bersemangat dan tidak merasa bosan.

Ruangan kelas perlu dikelola dengan baik, supaya kondisi dan suasana kelas menjadi lebih kondusif dalam melaksanakan pembelajaran. Kelas menurut Nawawi (dalam Erwinsyah, 2017) merupakan ruangan yang menjadi tempat berkumpulnya sejumlah siswa untuk mengikuti kegiatan pembelajaran. Pengelolaan kelas tersebut, disebut juga dengan manajemen kelas. Menurut Sofan, dkk (2014), manajemen kelas merupakan kegiatan guru dalam mengkondisikan kelas yang ideal untuk mencapai proses pembelajaran yang optimal. Selain itu, manajemen kelas juga merupakan segala usaha yang dilakukan guru untuk menciptakan suasana belajar mengajar yang efektif 
dan dapat memotivasi anak didik untuk mengikuti kegiatan pembelajaran dengan baik (Rusydie, 2011). Dari paparan diatas, dapat disimpulkan manajemen kelas adalah keterampilan guru mengelola kelas dalam kegiatan belajar mengajar dengan tujuan untuk menciptakan kondisi kelas yang kondusif, efektif, menyenangkan, dan memotivasi anak didik untuk belajar.

Pelaksanaan manajemen kelas dilakukan secara terstruktur dan sistematis. Implementasi manajemen kelas menurut Erwinsyah (2017) meliputi: perencanaan pembelajaran, pengarahan, pengaturan ruang kelas, komunikasi dan kontrol yang diimplementasikan untuk meningkatkan efektifitas proses belajar mengajar sehingga dapat meraih prestasi belajar anak didik. Warsono (2016) dalam penelitiannya menyebutkan bahwa pada tahap perencanaan guru dapat melakukan pengelolaan kelas dengan mengatur prasarana pembelajaran, kemudian mengelola pengajaran dan pengkondisian anak didik. Pada tahap pelaksanaan dilakukan dengan menerapkan beberapa prinsip pengelolaan kelas dan beberapa pendekatan. Pada tahap pengawasan dilakukan secara kontinu oleh kepala sekolah.

Djamarah (dalam Warsono, 2016) menyebutkan 6 prinsip pengelolaan kelas yang baik harus memenuhi unsur rasa hangat dan memicu rasa antusias, memberikan tantangan, kegiatan yang bervariasi, keluwesan dalam pembelajaran, pemberian penekanan pada hal positif dan penerapan kedisiplinan di dalam kelas.

\section{METODE PENELITIAN}

Penelitian ini menggunakan jenis penelitian korelasional tata jenjang dengan menerapkan pendekatan kuantitatif. Penelitian korelasional adalah penelitian yang berusaha untuk mengetahui ada tidaknya hubungan antara dua variabel atau lebih (Masyhud, 2016). Penelitian ini dilakukan untuk mengetahui ada tidaknya korelasi atau hubungan antara manajemen kelas dengan motivasi belajar anak di TK Bina Anaprasa Nuris kecamatan Sumbersari kabupaten Jember.

Metode analisis dalam penelitian ini menggunakan Rank Spearman (Spearman's Rho). Masyhud (2016:371) menjelaskan bahwa Rank Spearman digunakan untuk mengetahui ada tidaknya hubungan antara dua variabel. Rumus Rank Spearman (Spearman's Rho) sebagai berikut.

$$
\text { Rho }_{x y}=1-\frac{6 \sum D^{2}}{N\left(N^{2}-1\right)}
$$

Keterangan:

rho $_{x y}:$ koefisien korelasi korelasi tata jenjang

$1 \& 6$ : bilangan konstan

D : beda, yaitu selisih nilai ranking skor butir dengan skor total $\mathrm{N} \quad$ : banyak subjek (Masyhud, 2016).

Subjek penelitian ini adalah anak kelompok B TK Bina Anaprasa Nuris kecamatan Sumbersari kabupaten Jember dengan rentang usia 5-6 tahun yang berjumlah 14 anak. Metode pengumpulan data meliputi: a) angket, sebagai intrumen manajemen kelas; b) observasi, sebagai instrumen motivasi belajar; dan c) dokumentasi berupa data 
pendukung dalam penelitian ini yakni foto kegiatan, profil sekolah, daftar nama guru dan siswa serta data pendukung lainnya.

\section{HASIL DAN PEMBAHASAN}

Berdasarkan hasil analisis data menggunakan rumus korelasi tata jenjang terhadap hasil pengisian angket dan lembar observasi yang telah dilakukan, diperoleh nilai $\mathrm{r}_{\text {hitung }}$ sebesar 0,808 . Nilai tersebut lebih besar dari $\mathrm{r}_{\text {tabel }} 0,544$ (dengan $\mathrm{N}=14$ dan taraf kepercayaan 95\%).

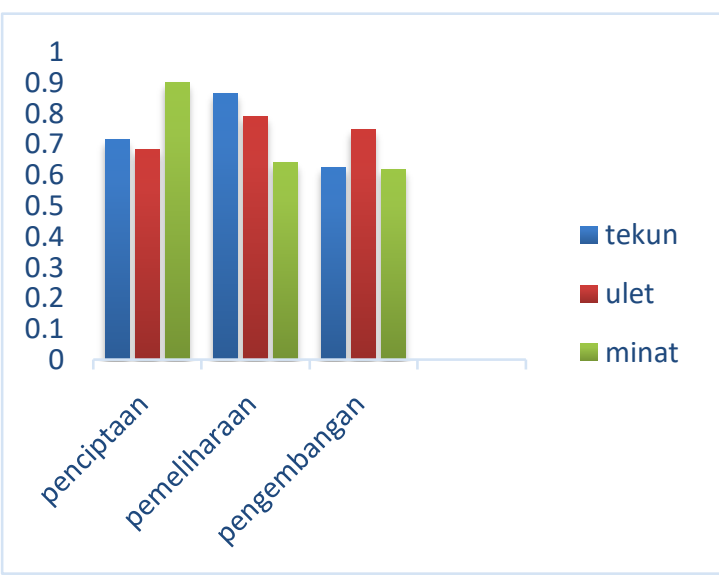

Gambar 1. Hubungan manajemen kelas dengan motivasi belajar

Hubungan antara manajemen kelas pada indikator penciptaan kondisi belajar jika dihubungkan dengan motivasi belajar pada indikator tekun menghadapi tugas terdapat hasil 0,714. Hasil dari hubungan antara manajemen kelas pada indikator penciptaan kondisi belajar jika dihubungkan dengan motivasi belajar pada indikator ulet menghadapi kesulitan terdapat hasil 0,684 . Hasil dari hubungan antara manajemen kelas pada indikator penciptaan kondisi belajar jika dihubungkan dengan motivasi belajar pada indikator menunjukkan minat terhadap macam-macam masalah terdapat hasil 0,90.
Hubungan antara manajemen kelas pada indikator pemeliharaan kondisi belajar jika dihubungkan dengan motivasi belajar pada indikator tekun menghadapi tugas terdapat hahsil 0,865. Hasil dari hubungan antara manajemen kelas pada indikator pemeliharaan kondisi belajar jika dihubungkan dengan motivasi belajar pada indikator ulet menghadapi kesulitan terdapat hasil 0,790 . Hasil dari hubungan antara manajemen kelas pada indikator pemeliharaan kondisi belajar jika dihubungkan dengan motivasi belajar pada indikator menunjukkan minat terhadap macam-macam masalah terdapat hasil 0,640.

Hubungan antara manajemen kelas pada indikator pengembangan kondisi belajar jika dihubungkan dengan motivasi belajar pada indikator tekun menghadapi tugas terdapat hasil 0,652. Hasil dari hubungan antara manajemen kelas pada indikator pengembangan kondisi belajar jika dihubungkan dengan motivasi belajar pada indikator ulet menghadapi kesulitan terdapat hasil 0,747. Hasil dari hubungan antara manajemen kelas pada indikator pengembangan kondisi belajar jika dihubungkan dengan motivasi belajar pada indikator menunjukkan minat terhadap macam-macam masalah terdapat hasil 0,619.

Analisis data yang digunakan teknik Rank Spearman (Spearman's Rho) yang merupakan teknik korelasi untuk melihat ada atau tidaknya hubungan antara dua variabel. Kriteria yang digunakan $n=14$ dengan $r_{\text {tabel }}$ sebesar 0,544 dalam taraf signifikan 95\%, atau jika dipresentasekan maka diperoleh nilai sebesar $65,24 \%$. Selanjutnya sisanya $34,76 \%$ dipengaruhi faktor lain. 
Berdasarkan data penelitian, hasil perhitungan uji hipotesis diperoleh $\mathbf{r}_{\text {hitung }}$ sebesar 0,808 , sehingga $\mathbf{r}_{\text {hitung }}>$ $\mathrm{r}_{\text {tabel }}, 0,808>0,544$, maka dapat disimpulkan bahwa adanya hubungan antara manajemen kelas dengan motivasi belajar. Dengan demikian, $\mathrm{H}_{\mathrm{a}}$ (diterima) dan $\mathrm{H}_{0}$ (ditolak).

Berdasarkan hasil temuan di lapangan, guru berperan penting pada peningkatan motivasi belajar anak, oleh karena itu pengelolaan pembelajaran harus disesuaikan dengan kemampuan anak didik. Guru menciptakan manajemen kelas yang baik dalam menghasilkan pembelajaran yang berkualitas. Manajemen kelas adalah semua usaha yang dilakukan untuk mewujudkan suasana belajar mengajar yang menyenangkan, dan dapat memotivasi belajar anak didik dengan baik (Rusydie, 2011). Secara umum, dapat diketahui bahwa salah satu hal yang menentukan motivasi belajar seseorang selain faktor individu juga faktor lingkungan, terutama lingkungan belajar (Dimyati dan Mudjiono, 2010). Oleh karena itu, keterkaitan antara manajemen kelas dengan motivasi belajar anak cukup baik jika diterapkan secara optimal.

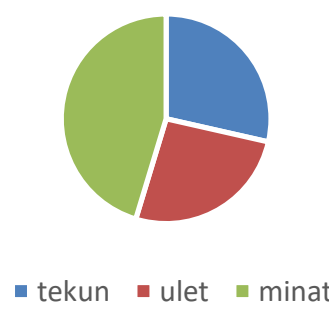

Gambar 2. Hubungan penciptaan kondisi belajar dengan motivasi belajar

Untuk memperjelas hasil temuan di lapangan, maka dipaparkan hubungan pada setiap indikator. Pada
Gambar2, diketahui hubungan antara penciptaan kondisi belajar dengan motivasi belajar (indikator tekun menghadapi tugas) sebesar 0,714 atau $51,02 \%$. Selanjutnya, hasil perhitungan antara penciptaan kondisi belajar dengan (indikator ulet menghadapi kesulitan) didapatkan hubungan sebesar 0,684 atau 46,72\%. Adapun hasil perhitungan dari hubungan antara penciptaan kondisi belajar dengan motivasi belajar (indikator menunjukkan minat terhadap macam-macam masalah) didapatkan hubungan sebesar 0,9 atau $81,00 \%$.

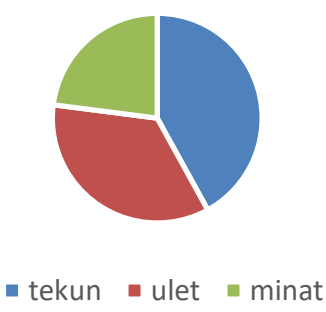

Gambar 3. hubungan pemeliharaan kondisi belajar dengan motivasi belajar

Berdasarkan gambar 3 di atas diketahui hubungan antara pemeliharaan kondisi belajar dengan motivasi belajar (indikator tekun menghadapi tugas) sebesar 0,865 atau $74,79 \%$. Selanjutnya, hasil perhitungan antara pemeliharaan kondisi belajar dengan (indikator ulet menghadapi kesulitan) didapatkan hubungan sebesar 0,790 atau $62,43 \%$. Adapun hasil perhitungan dari hubungan antara pemeliharaan kondisi belajar dengan motivasi belajar (indikator menunjukkan minat terhadap macam-macam masalah) didapatkan hubungan sebesar 0,640 atau 40,90\%. 


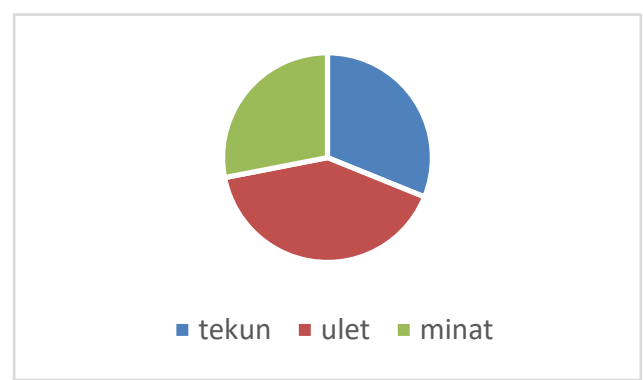

Gambar 4. Hubungan pengembangan kondisi belajar dengan motivasi belajar

$\begin{array}{rrr}\text { Pada gambar } 4 & \text { dijelaskan } \\ \text { tentang hubungan } & \text { antara } \\ \text { pengembangan kondisi } & \text { belajar }\end{array}$ dengan motivasi belajar (indikator tekun menghadapi tugas) sebesar 0,652 atau $42,54 \%$. Selanjutnya, hasil perhitungan antara pengembangan kondisi belajar dengan (indikator ulet menghadapi kesulitan) didapatkan hubungan sebesar 0,747 atau 55,76\%. Adapun hasil perhitungan dari hubungan antara pengembangan kondisi belajar dengan motivasi belajar (indikator menunjukkan minat terhadap macam-macam masalah) didapatkan hubungan sebesar 0,619 atau $38,34 \%$.

Kelemahan dalam penelitian ini, yakni; a) menggunakan teknik pengambilan data angket yang tidak mudah dipahami oleh semua anak, sehingga beberapa anak saja yang dapat memahami dan mengisi lembar angket, b) kurangnya responden, dikarenakan tidak semua responden dapat diambil, 14 anak dari 22 anak yang lolos uji coba pengisian angket. Apabila menggunakan angket dalam penelitian ini, sebaiknya bahasa dalam soal-soal angket harus disesuaikan dengan bahasa anak agar mudah dipahami oleh setiap anak.

\section{KESIMPULAN}

Hasil penelitian yang telah dilakukan menunjukkan adanya korelasi atau hubungan antara manajemen kelas dengan motivasi belajar anak kelompok B di TK Bina Anaprasa Nuris Jember. Hal tersebut diketahui dari perolehan hasil analisis data yang menunjukkan bahwa nilai $r_{\text {hitung }}>r_{\text {tabel }}=0,808>0,544$. Jika dipersentasekan maka manajemen kelas telah memberikan kontribusi pada motivasi belajar sebesar $65,24 \%$, sedangkan sisanya $34,76 \%$ dipengaruhi oleh faktor lain.

\section{DAFTAR PUSTAKA}

Amilda. 2017. Efektifitas Manajemen Kelas Kelompok Bermain pada PAUD Bon Thorif Palembang. Jurnal Pendidikan Islam Anak Usia Dini,1, 1-22. http://jurnal.radenfatah.ac.id/i ndex.php/raudhatulat hfal/article/view/1463. [diakses pada 21 Maret 2019]

Arikunto, S. 2010. Prosedur Penelitian Suatu Pendekatan Praktik. Jakarta: PT Rineka Cipta.

Badaruddin. 2015. Peningkatan Motivasi Belajar Siswa melalui Konseling Klasikal. Malang: $\quad \mathrm{CV} \quad \mathrm{ABE}$ Kreativindo.

Erwinsyah, A. 2017. Manajemen Kelas dalam Meningkatkan Efektivitas Proses Belajar Mengajar. TADBIR Jurnal Manajemen Pendidikan Islam. 5 (2): 87-105.

Masyhud, M. S. 2016. Metode Penelitian Pendidikan. Jember: LPMPK.

Montolalu. 2009. Bermain dan Permainan Anak. Jakarta: Universitas Terbuka. 
Nashar. (2004). Peranan Motivasi dan Kemampuan Awal dalam

Kegiatan Pembelajaran.

Jakarta: Delia Press.

Rusydie. 2011. Prinsip-prinsip Manajemen Kelas. Yogyakarta: Diva Press.

Sofan, dkk. 2014. Pengembangan dan Model Pembelajaran Tematik Integratif. Jakarta: Prestasi Pustaka.

Sutarman, M. 2016. Manajemen Pendidikan Anak Usia Dini. Bandung: CV Pustaka Setia.

Warsono, S. 2016. Pengelolaam Kelas dalam Meningkatkan Belajar Siswa. Manajer Pendidikan. 10 (5): 469-476

Zulqadri. 2015. Pengaruh Pengelolaan Kelas terhadap Motivasi Belajar Siswa Kelas XI IPS 1 di SMA Negeri 2 Binamu Kabupaten Jeneponto. Jurnal Sosialisasi Pendidikan Sosiologi, 2 (2), 116-119. 